\title{
大形低速ディーゼル機関の現状と展望 一三菱UE形機関*-
}

三菱重工業(侏では，1955年以来そのオリジナルの 設計により我が国唯一の舶用低速 2 サイクルUE形 ディーゼル機関を開発してきました．その開発の歷 史は50年近くを経て, 特長的な構造の変化を遂げ, 近年の高性能, 高機能ニーズを実現した機関へと成 長してきています．即ち，ストローク／ボア比が 3 を越える超ロングストローク機関で, シリンダ中央 に 1 個の排気弁を有するユニフロー掃気方式を採用 し, 総合効率が70\%にも達する高効率過給機を搭載 しています．機関の平均有効圧は， $1.7 \mathrm{MPa}$ ，平均 ピストン速度は, $8 \mathrm{~m} / \mathrm{s}$ 達成しており, 高レベル の出力率となっています.

三菱UEC形機関の特長は, シンプルな構造の上 に高い機関性能と信頼性を両立させている点にあり ます，機関性能は，熱効率 $50 \%$ を既に越え，世の中 の熱機関単体では, 最高の効率を誇っており, 使用 燃料の低グレード化も手伝って, 海上輸送の低コス 卜化, 効率化に貢献しています. 図 1 に現在開発中 のUEC-LS II 形機関シリーズの特長を示します. シリンダライナの掃気ポートの形状(CSSポート1) は，機関性能に及ぼす影響が大きく，性能向上の代 表的な例で，コンピュータを駆使したシリンダ内部 の非定常流動解析技術の枠を盛り込んで設計されて います．同様の技術が，燃料噴射系，排気弁駆動系， 排気ガス通路，過給機などにも盛り込まれ，機関の 性能を向上させてきました，さらに機関の信頼性向 上に関しても，有限要素法 (FEM) などによる機 関構造の積極的な最適化設計により，コンパクトか つシンプル化しながら信頼性を向上することに成功 しました。

\footnotetext{
*原稿受付 平成 6 年 9 月 26 日

**正会員 三菱重工業(侏神戸造船所

（神戸市兵庫区和田崎町 1-1-1）

***正会員 三菱重工業(侏神戸造船所
}

（神戸市兵庫区和田崎町 1-1-1）
本村 収** 若月祐 之**

さらに, 就航状況からフィードバックしてきたリ ング・ライナ摺動状況改善などで, 長期間無開放を 実現するに至りました。ここに至るまでは，当学会 をはじめ, 船舶を運航されている船主各位, 潤滑油 メーカー各位, 弊社研究所など多方面の協力を得て, 長期間にわたる調查研究に理解を頂いた結果であり ます．現在では，大形タンカー（VLCC）に搭載 されるUEC-LS II 形機関では，ドック・トゥ・ ドックのメンテナンスインターバルが通常になって います。

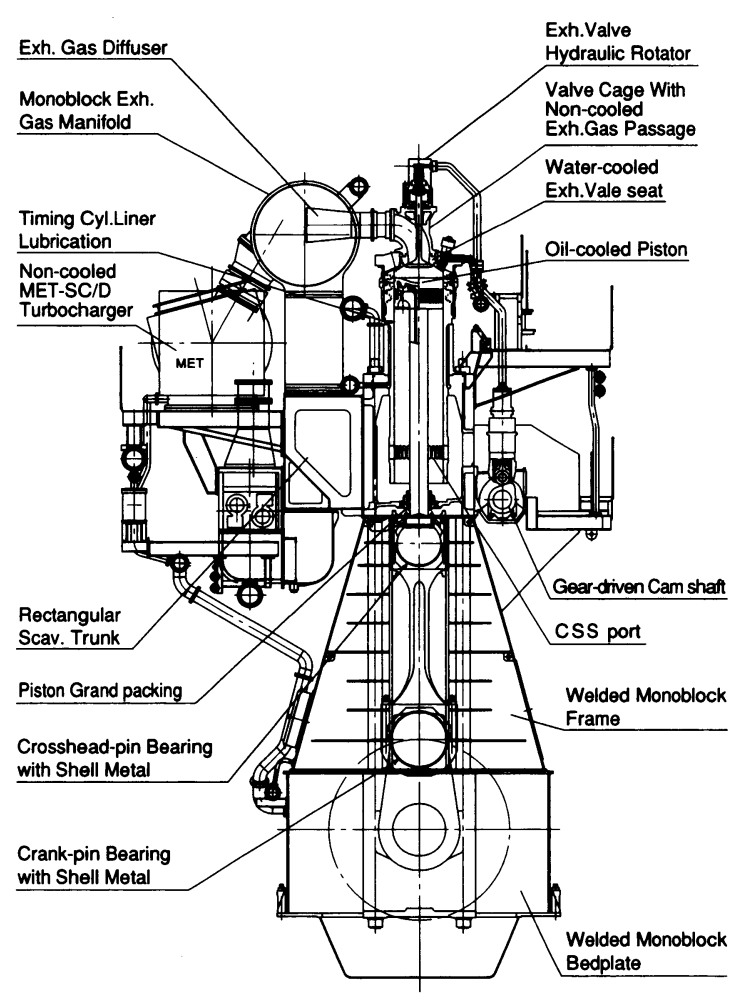

図 1 三菱UEC-LS II 形機関の特長 


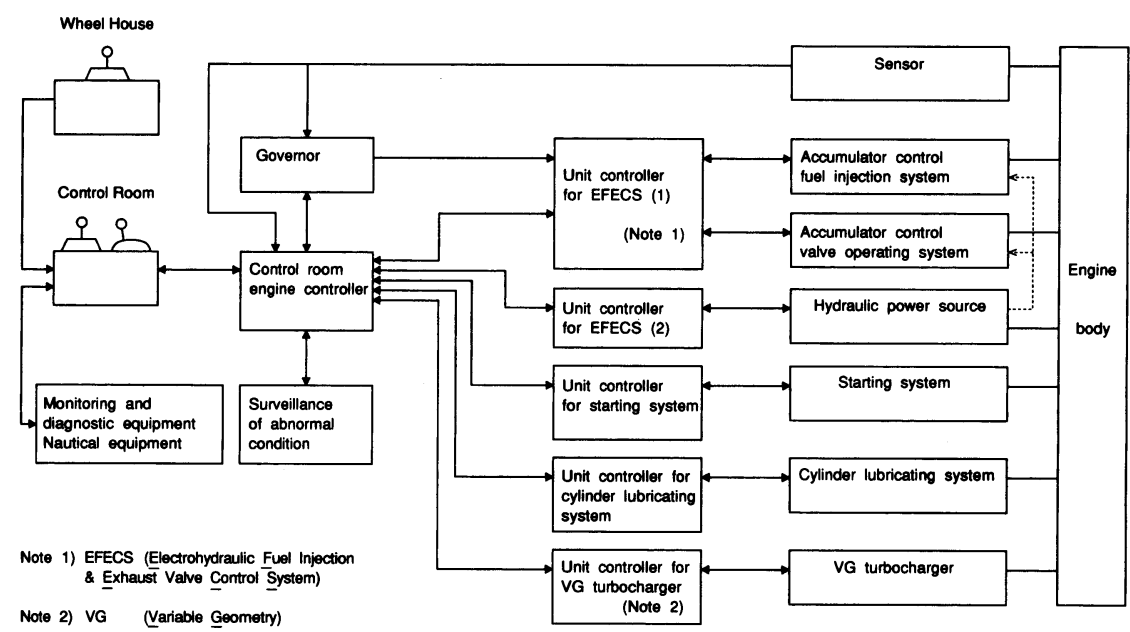

図 2 機関電子制御システムの概要

このように，最近の機関の性能および信頼性には 著しい進歩が見られます，同時に，燃料噴射系の重 質油発停仕様, 排気弁の油圧式駆動化，燃料噴射弁 の軽量化，シリンダジャケットの冷却部の低減，機 関振動への諸対策, ピストンクラウンの油冷却最適 化などの設計変更も進み現在に至っています.

さて, 今後のディーゼル機関の進む方向としては, 第一に地球環境に適した機関であることが必要とな ると考えられます．国連の海事機関であるIMOで は，長年にわたり船舶から排出される有害物質の規 制について議論されており，ディーゼル機関から排 出されるNOxやSOxがテーマとなっています．地 球環境に適応したディーゼル船は，全世界が海運界 に望んでいることです。第二に，コストの低減です。 特に日本の造船界は，昨今の不況と円高に苦しんで おり，燃料コストなどの運航費の低隇に加えて，船 舶の建造費についても大幅な削減の要求があり，そ れに連動して主機関であるディーゼル機関へもコス 卜削減の強い要求があります。コンパクトな本体か ら大出力が出せる機関の出現が望まれるわけです.

こういった市場ニーズに答える一手段として検討さ れているのが，機関の電子制御化です.

ここでは，主にこの電子化についてご紹介します. 現在, 舶用の大形主機関で電子化というと, 電子ガ バナーとリモートコントロールという所謂操縦系統 ということになりますが, 三菱重工業では, 将来の 機関の構想として, さらに一歩踏み込んで, 燃料噴 射ポンプ, 油圧排気弁駆動用アクチュエータ, シリ
ンダ注油器, 始動空気管制装置（弁）などの現在力 厶軸で駆動しているもの全てを電子制御化すること により, カム, ローラ, カム軸, 力ム軸駆動歯車な よ゙を主機関から取り去ってしまうアイディアにチャ レンジしています，すでに，当社の研究所で，単筒 の大形試験機関を用いて試験されており，実用化の 日もそう遠いことではないと考えています，図2に そのシステムの概要図を示します。制御の系統は, アイテム別に独立したコントローラを持ち，一つの システムの故障が他の制御系へ影響を及ぼすことを 避けています。また，電子制御化されたシステムは， 船舶の運航条件に合わせたセッティングが可能であ り，本システムでは，燃料噴射タイミング，排気弁 開閉弁タイミング，シリンダ注油量などを自在に変 更することが可能であります，従って，建造費の低 減に貢献するだけでなく，運航費の節減にも役立つ システムといえると考えます.

運航費の節減を追及したシステムの一例として, 図 3 に概要を示すAFR制御システム ${ }^{2)}$ があります. このシステムは, 機関の出力, 回転数および吸込み 空気温度を検知し，電子制御により制御されたCIT

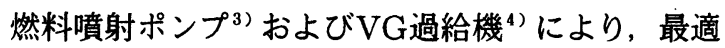
な燃焼状態を常に作り出すものです．このシステム を搭載すると, 過負荷域, トルクリッチ域, 低負荷 域, 熱帯地域航行時, 寒冷地域航行時などあらゆる 運航条件下で最適な機関性能の設定が可能で, 機関 内部では，常に適切な掃気圧力が提供され，適当な 燃料噴射タイミングが選定されます，本システムは 


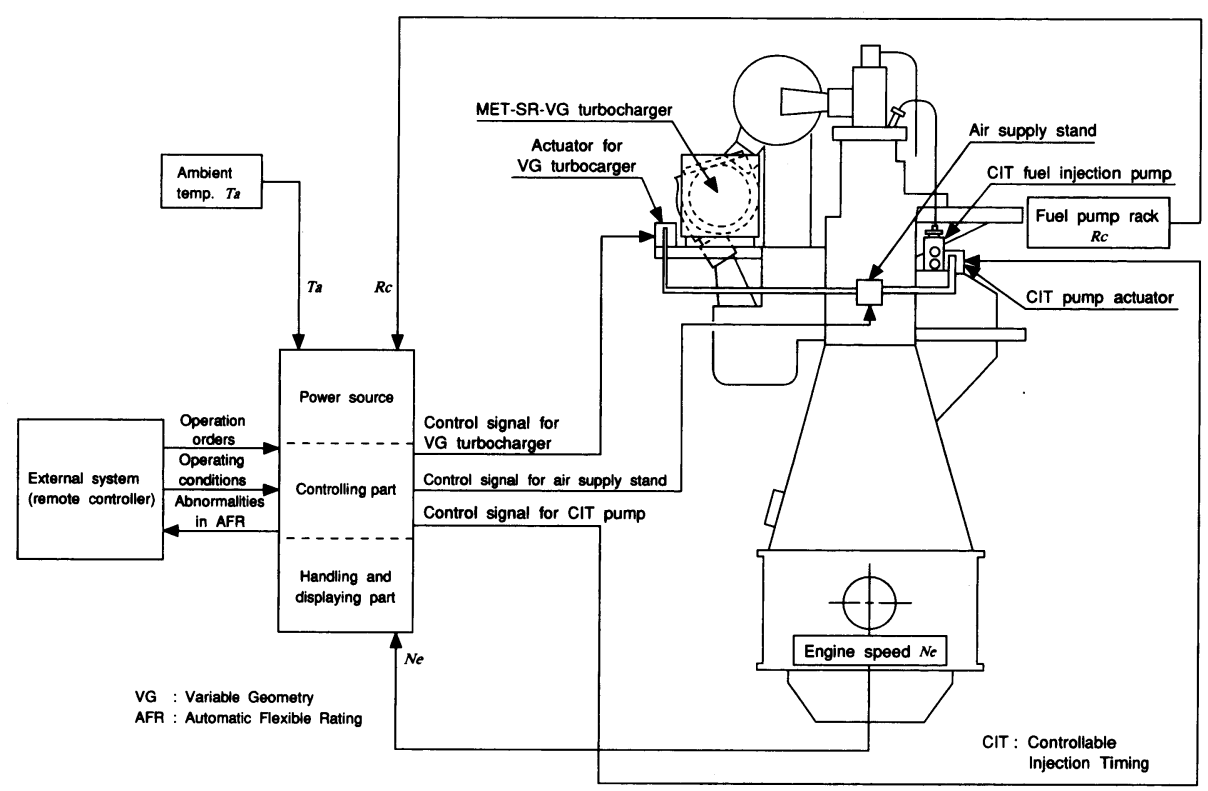

図 3 AFR制御システムの概要

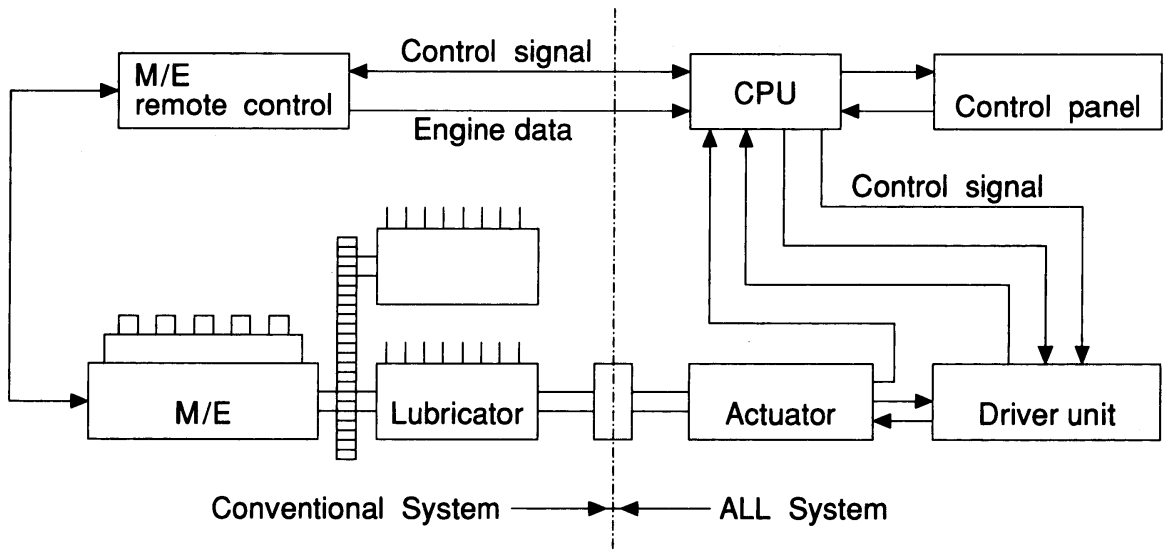

\section{図 4 ALLシステムの概要}

1988年に就航した大形タンカーの主機関 8 UEC75 LS IIに搭載されており，常に一定の筒内最高圧力 を示し，燃料消費率は良好なレベルで推移しました。 本船では, 現在もこのシステムが継続して稼㗢中で あり，本システムの高い信頼性も実証されました。

ディーゼル機関の信頼性が運航コストに及ぼす影 響は小さい値でないというのが共通の認識です．特 に，ピストンリングとシリンダライナの摺動部の摩 耗の問題は, 長い間機関設計者を悩ませてきた問題 の一つであります.この要因の一つに, シリンダ注
油の経済性という問題があります。シリンダ潤滑油 は, 石油メーカーのノウハウの詰まった添加剤が多 く含まれている非常に高価な潤滑油であり，その消 費量は運航コストに少なからず影響を与えています。 したがって，船舶運航者は，必要最小限の潤滑油を 供給するという役目を委されており，潤滑油を多過 ぎず，機関に少な過ぎず，といった運転を要望され ています。このような状況を改善するために，図 4 にその概要を示すALLシステム ${ }^{5)}$ が開発されまし た. 
本システムは，電子制御によりシリンダ注油量を コントロールして, 必要な時だけ増量し, 通常は減 量し，機関を保護しながら，総合的にシリンダ潤滑 油の消費量を低減していくというものです．シリン 夕゙注油量を増加させる時は, 出入港の低速運航時や 荒天時などの負荷変動の大きくなる時であり，機関 の負荷, 回転数を検知し, 適正なシリンダ注油を供 給します. 平水時の通常運航にもどれば, 徐々にシ リンダ注油量を低減し，必要量の供給を行います。 このシステムは, 現在では実用化されており, 順調 な稼働と，ピストンリング・シリンダライナの摺動 面の摩耗量の低減への貢献が評価され, 好評を博し ています.

将来的には，ピストンリングやシリンダライナの 摩耗センサーなどと本システムを結合して, 燃料油 などの外部からの原因による摩耗に対しても，対応 できるシステムとすることも考えられています．す なわち, 負荷以外の何らかの原因により摩耗量が増 大した場合, その摩耗量の増加傾向に応じて, シリ ンダ注油量を増加することにより, 摩耗の促進を止 め, 状況を安定させることができます．このような, システムが実現すれば，船舶運航者は，ピストンリ ングの摩耗やシリンダ潤滑油の消費量にとらわれる ことなく機関を運転することができます.

以上, 将来のUEディーゼル機関の電子制御化に 対する三菱重工業の考え方を紹介しました。 もちろ ん, 電子機器類の信頼性など, 解決しなければなら ない問題も少なくありません. しかし，これらの実 用化は，そう遠くない将来の話であり, その目的は, 機関メーカーのみでなく, 船主, 船舶運航者などの コスト低減に益することであると言えます。 また現 在, 大形のディーゼル機関に搭載する電子機器は, 大体において高価なものが多く，一見コスト低減に は継がらないように見られがちですが，現在の大き な機械部分の代替としての装置，あるいは運航管理 費の大幅な削減に継がることにその真の価值がある と考えます.

\section{注 釈}

1) CSSポート: Controlled Swirl Scavenging Ports

2) AFR制御システム: Automatic Flexible Rating Control System

3) CIT燃料噴射ポンプ : Controllable Injection Timing Fuel Oil Injection Pump

4) VG過給機 : Variable Geometry Turbocharger

5) ALLシステム : Automatic Cylinder Liner Lubricating System

\section{参考文献}

1) 平山, 宮野, 小野, 小山田, 下田 三菱UEC75LS II 形ディーゼル機関の開発 三菱重工技報 Vol.25 No. 3 (1988)

2 ) 田山 最近の三菱UEディーゼル機関 内燃機関 Vol.29 No.369 (1990)

3 ）田山, 若月 三菱UEC85LS II 形機関の開発 日本造 船学会誌 第741号 (1991)

4) 田山, 宮野, 入江, 新井 電子制御ディーゼル機関 日本舶用機関学会誌 第26巻第 5 号 (1991)

5 ) 吉村, 本村, 近藤, 田山 AFRシステム装備大形ディー ゼル機関の就航実績 日本舶用機関学会誌 第26巻 第 8 号 (1991)

6 ) 若月 低質燃料油に対する三菱UEC形ディーゼル機 関 造船技術 Vol.24 No.10 (1991)

7 ) 三井, 永瀬, 小野, 入江 舶用ディーゼル機関のシ リンダ注油電子制御装置の開発 三菱重工技報 Vol.29 No. 1 (1992)

8 ) 本村, 近藤, 岡部, 下田, 幕田 三菱UEC $85 L S$ II 形 ディーゼル機関の開発 三菱重工技報 Vol.29 No. 3 (1992) 